\title{
INTRODUCTION TO SPECIAL ISSUE: ASSIMILATION, INTERRUPTED: TRANSFORMING DISCOURSES OF CULTURE- AND HONOUR-BASED VIOLENCE IN CANADA
}

\author{
Mandeep Kaur Mucina and Amina Jamal
}

\begin{abstract}
This special issue about race, honour, culture, and violence against women in South Asian Canadian communities is proffered as an entry point to a wider, multilayered discussion about race, culture, gender, and violence. It hopes to intensify a debate on gendered violence that could tie in with analysis and commentary on individual killings in family-related sites, murders of racialized women and girls in public sites, and other forms of violence against women and girls in society. We encourage readers to consider how to understand the landscape that South Asian Canadian women and girls are confronting, while also asking critical questions about the wider settler colonial system in which we all participate as we fight gender-based violence.
\end{abstract}

Acknowledgements: As uninvited multigenerational immigrants on Lkwungen peoples' territories (Mandeep) and Anishinaabe, Mississauga, and Haudenosaunee territories (Amina), we affirm our gratitude to the Indigenous communities of Turtle Island on whose traditional land we currently live and work. We acknowledge Indigenous communities' ongoing fight against genocide, their resistance to colonial occupation of Indigenous land, water, and other resources, and their struggle to reclaim Indigenous governance.

We thank the authors who started this journey with us almost eight years ago. Our idea was to gather academics, activists, and practitioners who were fighting racist discourses surrounding South Asian Canadian women and communities while supporting and caring for women and girls who struggle everyday with violence, racism, and sexism. We especially acknowledge Farrah Khan and Deanna Ida, whose initial voices, contributions, and editorial support made this issue possible. We would also like to acknowledge the reviewers who provided challenging and supportive feedback to each of the articles, and to recognize their generosity in giving time and support to each of the papers in this collection. We are grateful to the students and research assistants who supported this collection of papers over the years, including Sydele Merrigan, Alina Reed, and Binish Ahmed as well as our editors Susan Scott, and Leslie Prpich.

Finally, we would like to acknowledge the multigendered and cross-cultural victims and survivors of honour- and shame-related violence, whose stories serve as resources and sites for collective feminist pain and memorializing.

Mandeep Kaur Mucina PhD (corresponding author) is an Assistant Professor in the School of Child and Youth Care, University of Victoria, 3800 Finnerty Road, Victoria, BC V8W 2Y2. Email: mmucina@uvic.ca

Amina Jamal PhD is an Associate Professor in the Department of Sociology at Ryerson University, 350 Victoria Street, Toronto, ON M5B 2K3. Email: amina.jamal@ryerson.ca 
It was a typical December evening when a group of South Asian Canadian women from across Toronto gathered at the women's centre on a university campus. Many of us knew each other or had encountered each other in various spaces throughout Toronto, yet that particular evening we were not concerned with introductions or updates on our lives since we had last seen each other. We came together with a shared concern. We had been called together through a Facebook invitation to South Asian Canadian women who needed to process what had happened earlier that day and the night before. A 15-year-old girl, Aqsa Parvez, had been murdered by her father and brother at their family home in Mississauga, Ontario. Aqsa Parvez's death was on the front page of every major media outlet. We were stunned by the whirlwind that enveloped the city after her death and needed a place to come together to debrief and process what this all meant and how we would respond personally and collectively. Feeling shocked and betrayed by the murder, and fuelled by the fear and anger burning in the back of our throats, we talked about the way her murder was framed in the media. With perverse pride, Aqsa Parvez's death was termed Toronto's first honour killing (Rogan, 2008) in mainstream media. We were concerned about the impact this framing would have on brown women, the Muslim community, and young girls who were already feeling silenced by the racism, sexism, and Islamophobia they experienced every day. That day marked a turning point for many of us who had been working with South Asian Canadian families and communities across the Greater Toronto area in the gender-based violence sector. We were educators, social workers, community activists, and allies who understood the profound impact Aqsa's death would have on all of us.

What emerged from that group came to be known as Aqsazine ${ }^{1}$, a collective of Muslim women and girls who channelled their anger, fear, resistance, and creativity into a web-based "zine" that centred the voices of Muslim women who were impacted by Islamophobia, racism, and sexism. Led by Farrah Khan and carried forward by other South Asian Canadian women in Toronto, the original collective has undergone multiple transformations over the years. Yet the work, tears, pain, and fight continue to this day, and the important questions we asked ourselves in the wake of Aqsa's death are refreshed each time a girl or woman experiences shame, exclusion, or violence, or is murdered, in the South Asian community in Canada. Many articles were written in response to Aqsa's death (Haque, 2010; Olwan, 2014, 2019; Weldon, 2010) and about the media's role in perpetuating Islamophobia (Jiwani, 2014). We acknowledge the work that has occurred in the past decade to address and engage with the discourses that emerged in the post-9/11 world and after Aqsa's death. Nevertheless, we want to shift the focus back to the complex ways racism and gender-based violence intersect when violence in the name of honour shows up in public discourses.

This collection of papers brings a new critical approach to the existing literature on honourand shame-related violence and relevant prevention measures. There is a plethora of recent journal

${ }^{1}$ https://zeedesigns.wixsite.com/aqsazineonline 
International Journal of Child, Youth and Family Studies (2021) 12(1): 1-12

articles on this subject in disciplines as diverse as sociology, law, Aboriginal studies, religion, immigration and settlement studies, geography, cultural studies, ethics, psychology, social work, and politics. As well, honour-related violence continues to be discussed in global conferences and forums organized by state and non-state actors in North America and Europe each year. Indeed, discussions of "honour killing" tend to figure as a type of marginal or contextual violence in research and scholarship on youth, children, and families. Less discussed, however - as we found in the wake of Aqsa's tragedy - are the problems caused when an incident of gendered violence emerges as a racialized discourse in media, political, and popular forums. Such discourse not only implicates the relationship between victim and perpetrator but also acquires the potential to unsettle many other kinds of relationships: intimate, private, and public.

This special issue seeks to emphasize the specificity of honour killing as a form of violence that is ultimately related to sexuality and embodied transgression, largely impacting women and girls. It begins from the cognizance that sexual violence against racialized women and girls represents a key site of contestation over rights — state versus community, secular versus religious, local versus global, and individual versus community and group (Jamal, 2015; Mucina, 2018). As such, racist discourses of culture and immigrant communities not only obscure the role of racialization, state formation, and nation building in constructing notions of civilized selves and uncivilized others, but also limit opportunities for expressions of grief and outrage and claims for community accountability by women and girls in minority ethnic communities. The associated discourses of honour, shame, and violence obstruct opportunities for a wider intercommunity dialogue on the interaction of race, gender, class, and immigration, create new modes of gendered subordination, and deepen historical racial divides between Whites and non-Whites (Thobani, 2000); such dialogues could also become sites for South Asian solidarities with Black and Indigenous struggles.

\section{Culture, Race, Violence}

The invocation of the terms "honour" and "shame" in relation to violence against racialized women and girls is fraught with contestations and contradictions, since the relationship of gendered violence with race and culture that was established through colonialism continues to dominate all local, national, and transnational discussions. Under these conditions, an issue on "honour"-related violence is in danger of engaging in what Sherene Razack, in this publication and in her work more generally (Fellows \& Razack, 1998; Razack, 2003, 2004, 2008), calls "culture talk", often heard in legal responses to violence, which tends to culturalize and racialize the violence. Razack notes that culture talk becomes a pedagogy for training different groups of citizen-subjects about their collective cultural superiority or inferiority. Indeed, we are painfully cognizant that terms such as "honour killing" and "forced marriage" are taken in Western societies as applying only to racialized bodies. The image of women and girls who are "victims" of their culture and the image of "barbaric" men who perpetuate violence because of culture or religion are conjured in the Canadian imagination as bodies that need to be civilized and controlled (Abu Lughod, 2010; Haque, 2010; Korteweg \& Yurdakul, 2010; Mucina, 2018; Razack, 2007). In our 
everyday encounters with the media and dominant narratives in the West, we find a type of racism that is disguised in the language of protection and safety; it suggests that honour-related violence is a problem embedded in culture and religion that can only be tackled if racialized families and communities are fully assimilated into Western society and have internalized Eurocentric values.

\section{Transnationalism of Honour- and Shame-Related Violence}

The coverage of honour-related violence in the media has continued in a steady stream over the years. It has become a basis for changing policies at the governmental level and a focus of funding activity at the nongovernmental level, in addition to fuelling the Western popular imagination with images of the Orientalist East. Meanwhile, global shifts and changes have impacted marginalized and marked bodies across North America: Muslim women are targeted for their hijabs, brown men are marked as terrorists or defined as barbarians practising violent religions, and Black and Indigenous struggles have intensified against their daily encounters with systemic racism and violence. In the context of Islam, secularism, and the War on Terror, the global construct of honour becomes, in the words of Inderpal Grewal (2013), "an over determined concept - the preferred term, in many regions, for practices linked to reputation, pride, masculinity, or respectability. Honour enables sexual, economic, and political control, through gendered violence and governmentality, and through the protection of women" (p. 15). Grewal has used the phrase "outsourcing patriarchy" to recognize the participation of corporate and transnational media in producing and deploying narratives of cultural difference, and has pointed out the varieties of material profits that accrue from such discourses. An important insight from Grewal's notion of outsourcing patriarchy is that it links nations, states, feminist movements, nongovernmental organizations, and capitalist formations across and within first and third world contexts. It also points to the production of class, rural/urban, tribal/civilized, and national/communal differences that inhere in iterations of gendered notions of honour, regardless of whether their thrust is to eradicate honour killings or uphold them (Grewal, 2013). We suggest that these transnational flows of essentialist ideas constructed as honour killing need to be situated in the coalescing of post-9/11 Eurocentric cultural assertions, widespread Islamophobia, and racist notions of Muslim inassimilability and also existing and new projects of global militarization, transreligious capitalisms, religious extremism, and patriarchal domination in all contexts.

Taking a transnational feminist approach to honour killing in Canada enables us to explore the kinds of subjects that are produced through the boundary between secularism and Islam that is sustained by the honour-killing discourse. We can discern its potential as a hegemonic construct that both divides and connects seemingly disparate sites, localities, and subjects to produce what Afsaneh Najmabadi (2008) has described as "unavailable spaces" or "unavailable intersections" that feminists might crave and that also make particular "speaking as" demands on us (p. 70). For Muslim women it is hard to challenge both Islamist misogyny and imperialism from the same space, and very often attempts by feminists of Muslim background lead them to tread the same ground to which many misogynist Muslim groups have previously laid claim (Najmabadi, 2008, p. 75). Indeed, the discourse of honour killing creates one such "unavailable intersection" in both 
Western and Muslim majority states. In our attempts to challenge secular conceptions of freedom and resistance that sustain racist narratives of Muslim women's victimhood and drive imperialist projects for their rescue, postcolonial feminists reinstate alternative modes of subjectivity and agency for Muslim women that represent them as proud and pious members of their religious communities. To challenge secular or universalist projects for women's emancipation, LGBTQ2IA + rights, and human rights, critical scholars bring into focus alternative ideas about gendered agency (Abu-Lughod, 2010; Mahmood, 2005) and other conceptions - especially religious and cultural ones - about social collectivity (Razack, 2007; Spivak, 2005) and emergent transnationally produced local subjectivities (Grewal, 1999; Spivak, 1996).

\section{Clearing Space for Grief and Resistance}

Where neither state nor civil society offers an effective resolution to violence against women, postcolonial scholars turn to "community". One may ask, how is community constructed and upheld outside of the pervasiveness of multicultural discourse that defines it in terms of race, religion, and culture? Beyond the processes of regulation imposed by the legal, political, and cultural context of the dominant society, communities have their own practices of power and processes of regulation and disciplining. What avenues can women expect to find within communities without invoking identitarian notions of culture or religion that ultimately bolster the authority of law and the state? How can community-based solutions be effectively developed for the needs of those members who threaten to dismantle the community itself? How can families approach a community for support, guidance, and treatment when that same community may be the source of gendered violence?

In this special issue we seek to draw attention to aspects of gendered experience, emotions, and women's and girls' agency that are occluded by the notion of "honour killing", which can sever honour from shame, freedom from oppression, piety from sinfulness, deserving from undeserving, and normal from deviant. How can researchers, practitioners, and feminists offer more complex accounts of racialized women's subjectivities even as we attempt to dismantle colonial constructions and imperial narratives about the superiority of Western secularism, tolerance, and gender equality over barbaric and intolerant "Other" cultures and communities? In our attempts to deconstruct the colonial divisions of modernity versus tradition, secular versus religious, and civilized versus barbaric, we also ask, what is society's accountability towards survivors of honour-based violence - especially those who have been targeted or expelled from the family, community, or nation for their "dishonourable" quest for social, cultural, or sexual autonomy? Indeed, gendered subjects — women, queer men and women, and transgendered people - who are targets of family and community violence in a racist context tend to be erased or inadvertently counterpoised to family, community, religion, and culture when critical feminist researchers and practitioners focus only on context and not on the intersecting markers that contribute to the violence they may experience. 
We do not present this special issue as an all-encompassing discussion of violence against racialized women and girls or as a compendium of the varieties of racialized, sexualized, and gendered violence experienced in Canada. Indeed, this special issue about race, honour, culture, and violence against women in South Asian Canadian communities is proffered as an entry point to a wider, multilayered discussion about race, culture, gender, and violence. It hopes to intensify a debate on gendered violence that could tie in with analysis and commentary on individual killings in family-related sites, murders of racialized women and girls in public sites, and other forms of violence against women and girls in society. Such a debate would explicate, for example, the discursive and material linkages between the high level of media attention towards the deaths of young South Asian and Muslim women and girls who are victims of "honour killings" (Haque, 2010; Korteweg \& Yurdakul, 2010; Mucina, 2018) and the glaring lack of media interest in the more than 4,000 Indigenous women in Canada who have been murdered or gone missing since 1980 (Tasker, 2016), whose stories have been silenced by comparison (National Inquiry into Missing and Murdered Indigenous Women, 2019; Native Women's Association of Canada, 2009).

The inadequate recognition on the part of the state and the media of these unsolved murders, deaths, and disappearances of Indigenous women is a vital aspect of all discussions related to gender-based violence against women, girls, and LGBTQ2IA+ people, if we are to develop a complex, multifaceted, feminist understanding of women and violence. Recognizing our own complex entry points into current colonial structures, it is important to acknowledge that our fight against racism and sexism in migrant communities comes at a cost for Indigenous communities. Racialized immigrants often enter this settler colonial system to gain rights, while resisting and fighting the racism, patriarchy, and sexism they experience from the minute they arrive. Yet, to engage the state about access, rights, and acknowledgement is indeed asking for acceptance from a colonial system created through the genocide and dispossession of Indigenous people and land (Tuck \& Yang, 2012). How do migrant women and girls converse with Indigenous women, girls, and communities who are fighting for sovereignty while dismantling colonial systems of genocide and dispossession? This question has not been fully grappled with in this special issue: these discussions are often on the periphery as we live and engage with colonial systems in segregated community spaces that divide and conquer through "band-aid" solutions. These colonial structures rely on divisions created on the basis of race, class, and gender to maintain White supremacy and settler colonial occupation of unceded lands across the nation. Breaking down these pillars of colonialism requires immigrant and racialized communities to confront the allure that comes from emulating White supremacy and gaining privilege through capitalist desires and benefits in the form of funding, rights, and freedom for some but not all. This issue encourages the reader to consider how to understand the landscape that South Asian Canadian women and girls are confronting, while also asking critical questions about the wider settler colonial system in which we all participate as we fight gender-based violence. So, with humility and acknowledgment of the work our Indigenous sisters engage in to dismantle colonialism and uphold their traditional knowledges while surviving the onslaught of violence perpetuated by the state, we take up space 
International Journal of Child, Youth and Family Studies (2021) 12(1): 1-12

with this special issue to bring attention to racialized and gendered violence against South Asian Canadian women and girls.

\section{Article Highlights}

The authors in this volume speak from and to a wide range of individual and collective experiences and subjectivities, and theorize notions of honour and racialized bodies, and of culture, sexuality, and violence in unique ways. We include academics, community workers, cultural activists, artists, and first-voice survivors who share the complexities of honour-based violence while offering insights into how they worked to address the systems that perpetuate cultural racism towards racialized bodies.

As shared in the beginning of this introduction, the seeds planted after Aqsa Parvez's death stirred much emotion and action among South Asian Canadian women and girls in Toronto. Similarly, many voices in the social service sector stood up against the cultural racism that permeated the Conservative government of the day and the policies and practices that emerged. In the post-9/11 world, where those who are brown, Muslim, and from the East are often vilified and policed, the authors in this special issue all engage with the systems that perpetuate sentiments of cultural racism against South Asian Canadians, and invite surveillance of women and girls and their families in that community. All the authors draw on scholarship and research to investigate meaningful questions about the role of culture in honour-based violence and how policies and practices affect South Asian Canadian girls, women, families, and communities, and ultimately shape the kind of support and services we in the service sector provide to this population. Many of the authors are not speaking to child and youth practitioners in particular, but to all state-level actors who work with children, youth, families, and communities, examining our activities as practitioners working in diverse and multiracial contexts across Canada. It is time to bring diverse stories to frontline work. For those who are new to discourses about honour-based violence, forced marriage, and how these intersect with gender-based violence, this special issue will ask you to consider a number of questions presented by each author.

In the first paper we offer in this collection, Mandeep Kaur Mucina writes from the location of a second-generation Punjabi Canadian woman living in Canada. Working with conceptual frames that attempt to dismantle current discourses surrounding honour-related violence, Mucina weaves in letters to South Asian Canadian women and girls and the wider South Asian Canadian community. Her aim is to engage with discourses of honour that have had a silencing effect for women and girls from South Asian Canadian communities who have experienced honour-related violence. She unpacks some of the ways honour works in the lives of women like her, exploring the polemical pressures they face. On the one end, there is a colonial, racist gaze on the lives of these women, who are deemed to need saving from their "barbaric" cultures; on the other end, there are women and girls experiencing honour-related violence who silence their stories. Mucina skilfully complicates honour, called izzat in Punjabi; she explores the conventional meaning of honour as a merely oppressive tool and sheds light on its multiple dimensions. She makes a case 
for "coming to voice" and pays special homage to women whose lives have been lost or impacted by honour-related violence and to those who are otherwise affected by it. She ends with a collective letter written by survivors of honour-based violence that speaks to the powerful ways women and girls demand space to express the complex ways they have reclaimed their relationship to izzat and to their bodies as they heal from the trauma of expulsion from their families and communities.

Sherene H. Razack's article unmasks the powerful ways in which global media operates to crystallize and construct the image of the "barbaric", "backward", "violent", "uncivil" racial "others" who perpetrate violence against racialized women of Indian, Middle Eastern, and Muslim origins. Razack is cautiously uncertain about the value of a culturally specific understanding of honour-based violence in law. She says, "One thing that all patriarchies produce: a proportion of violent, out-of-control men, and sometimes families, who do their killing of women in culturally specific ways" (p. 44). She examines what she argues is a misplaced emphasis on a legal response in relation to well-known cases of honour-based violence against women, specifically the Aqsa Parvez murder and the Shafia family murders, and instead argues for a community-based response that is multilayered and culturally nuanced. When communicating information pertaining to "honour"-based crimes, Razack states that racist "cultural details are really part of a pedagogy, intending to convey to Canadians a message of their racial and cultural superiority with respect to the accused" (pp. 41-42). She makes the case that effective anti-violence work would recognize the way that racism and patriarchy intersect. She advocates for social service delivery frameworks that include an antiracist focus and training, which she asserts can produce substantive solutions to converging patriarchies (Eastern and Western) that are violent towards women.

In a reprint of her 2015 article $^{2}$, Amina Jamal critiques both Eurocentric scholars and postcolonial feminists for reinscribing a dichotomy that renders Muslim women as either "modern" secular subjects or "pre-modern" religious subjects. Mindful of the racist Orientalist gaze, she carefully confronts sexuality-related honour violence against women in Canada and Pakistan, both theoretically and empirically. She opens the article by presenting critiques of liberal postcolonial feminist and other logics that construct the binary of the "backward", pious, Muslim woman or the "modern" (and more liberal and secular) Muslim woman victim-subject. Taking a faith-based, though not theological, feminist approach, she unpacks the idea that Islam forces sexual repression. Included in Jamal's analysis is sexuality-related violence experienced by those of LGBTQ2IA+ (nonheteronormative) identities. Jamal says that Muslim women are situated in locations which crave intersections that are not currently considered in literature and theology. This craving produces what she names "transgressive piety" for those who are struggling to remain in their faith community. She develops this concept by drawing on examples from Islamic history, showing that transgression is constitutive of a model of Islamic piety and is within rather than outside the faith tradition. The author's focus on transgressive piety is especially important for

\footnotetext{
${ }^{2}$ Jamal's article is reprinted with permission from A. Jamal (2015), "Piety, transgression, and the feminist debate on Muslim women: Resituating the victim-subject of honor-related violence from a transnational lens", Signs: Journal of Women in Culture and Society, 41(1), pp. 55-79. It appears here for the first time in an open-access journal.
} 
International Journal of Child, Youth and Family Studies (2021) 12(1): 1-12

Muslim women who do not wish to reject their faith but instead wish to work from within their religious identity to assert their dignity, rights, and sense of belonging.

Salina Abji and Anna Korteweg ask whether there is utility in a culturally specific understanding of honour- and gender-based violence, tracing the shifts in policy from a Conservative government concerned with what it termed "barbaric cultural practices" to the current Liberal one that erases culture from gender-based violence. The authors take the position that culture does, in fact, play a role within both majority and minority communities, but that it does different work in different contexts and needs to be treated with nuance. They write that culture is about "the everyday meaning-making processes and practices that shape women's experiences" (p. 84).

Wendy Aujla engages directly with the criminal justice system and how that system understands and responds to honour-based violence, including forced marriages. For the study presented here, she interviewed police officers and civilians in Alberta police agencies. Using a written vignette of a young woman to illustrate a scenario of forced marriage, she engages in conversations with the police officers and civilians to determine how they would recognize and respond to honour-based violence in their work. Aujla's work unpacks the role of the police in the lives of women, girls, and their families and offers insights for advocates on what constitutes safety in the eyes of the police.

Deepa Mattoo and Sydele Merrigan provide an overview and critical analysis of Bill S-7, the Zero Tolerance for Barbaric Cultural Practices Act of 2015. This act came into effect post-9/11 under a Conservative government and helped to shape culturally violent narratives of Muslim and immigrant communities in Canada and their families. Mattoo and Merrigan blame a complicity among multiple actors - community, community leaders, family, individuals, institutions, policymakers, and legislators - for perpetuating such violence and provide policy recommendations to address gaps in the service system and other support structures. Mattoo and Merrigan's paper emphasizes that the knowledge and expertise of racialized women survivors and activists must be integral to, rather than merely a context for, measures and actions to address violence against women. Unless this is done, they argue, state attempts to address violence against racialized women will reiterate the colonial legacy that deprived racialized women of rights and dignity and served to bolster power differences between and within communities.

We end with a reflective piece, not research based, that offers more of a conceptual understanding of honour-based violence. Kelly Train's paper offers a personal account of working within the education system to engage with postsecondary students on the consideration of culture. Train positions herself as a sociology instructor in downtown Toronto; she has taught a course on family violence for over a decade. She draws from her years of experience with a diverse group of students in the classroom and from themes that emerged when discussing "honour-based violence" and violence against women in general. She notes that racialized Muslim students, as well as White students, see Islam and Islamic cultures as more patriarchal than the West in terms of violence 
towards women. At the same time, they view Western patriarchal forms of violence against women as less extreme and as the product of individual behaviour, rather than being systemic. Train discusses how she unpacks the students' perceptions with them, asking important critical questions and reminding them that violence against women is found in all patriarchal cultures, including Western societies. Additionally, she notes, no patriarchal culture can be regarded as not oppressive of women; instead, each applies oppression and violence in its own way.

We, the editors, hope these deconstructions and reconstructions of "honour killing" will clear a space for interdisciplinary discussions and debates about racialized and gendered forms of violence that connect the private and public lives of children, youth, families, and communities. We acknowledge the limited and partial nature of our work and thank in advance those researchers, activists, and artists who will take this discussion further in the future. 
International Journal of Child, Youth and Family Studies (2021) 12(1): 1-12

\section{References}

Abu-Lughod, L. (2010). Seductions of the "honor" crime. Differences: Journal of Feminist Cultural Studies, 22(1), 17-63. doi:10.1215/10407391-1218238

Fellows, M. L., \& Razack, S. (1998). The race to innocence: Confronting hierarchical relations among women. The Journal of Gender, Race \& Justice, 1, 335-351.

Grewal, I. (1999). Women's rights as human rights: Feminist practices, global feminism and human rights regimes in transnationality. Citizenship Studies, 3(3), 337-354. doi:10.1080/13621029908420719

Grewal, I. (2013). Outsourcing patriarchy: Feminist encounters, transnational mediations, and the crime of "honour killings." International Feminist Journal of Politics, 15(1), 1-19. $\underline{\text { doi: } 10.1080 / 14616742.2012 .755352}$

Haque, E. (2010). ). Homegrown, Muslim and other: Tolerance, secularism, and the limits of multiculturalism. Social Identities, 16(1), 79-101. doi:10.1080/13504630903465902

Jamal, A. (2015). Piety, transgression and the feminist debate on Muslim women: Transnationalizing the victim-subject of honor-related violence. Signs: Journal of Women in Culture and Society, 41(1), 55-79. doi:10.1086/681771

Jiwani, Y. (2014). A clash of discourses: Femicides or honour killings? In M. Eid. \& K. H. Karim (Eds.), Re-imagining the other (pp. 121-152). Palgrave Macmillan. https://doi.org/10.1057/9781137403667_ 7

Korteweg, A., \& Yurdakul, G. (2010). Religion, culture, and the politicization of honour-related violence: A critical analysis of media and policy debates in Western Europe and North America. United Nations Research Institute for Social Development.

Mahmood, S. (2005). Politics of piety: The Islamic revival and the feminist subject. Princeton University Press.

Mucina, M. K. (2018). Exploring the role of "honour" in son preference and daughter deficit within the Punjabi diaspora in Canada. Canadian Journal of Development Studies, 39(3), 426-442. doi:10.1080/02255189.2018.1450736

Mucina, M. K. (2018). Daughters of honour: Navigating and resisting honour-related violence in the diaspora. Federation of Community Social Services of BC Research to Practice Network. https://fcssbc.ca/sf-docs/r2p/2018_mucina.pdf

Najmabadi, A. (2008). Teaching and research in unavailable intersections. In J. W. Scott (Ed.), Women's studies on the edge (pp. 69-80). Duke University Press.

National Inquiry into Missing and Murdered Indigenous Women and Girls. (2019). Reclaiming power and place: The final report of the National Inquiry into Missing and Murdered Indigenous Women and Girls. https://www.mmiwg-ffada.ca/final-report/ 
International Journal of Child, Youth and Family Studies (2021) 12(1): 1-12

Native Women's Association of Canada. (2009, March). Voices of our sisters in spirit: A report to families and communities (2nd ed.). https://www.nwac.ca/wpcontent/uploads/2015/05/NWAC Voices-of-Our-Sisters-In-Spirit_2nd-Edition_March2009.pdf

Olwan, D. M. (2014). 'No place in Canada': Triumphant discourses, murdered women, and the 'honour crime'. In A. K. Gill, C. Strange, \& K. Roberts. (Eds.), 'Honour' killing and violence (pp. 218-236). Palgrave Macmillan. doi:10.1057/9781137289568 11

Razack, S. (2003). A violent culture or culturalized violence? Feminist narratives of sexual violence against South Asian women. Studies in Practical Philosophy, 3(1), 80-104. doi:10.5840/studpracphil2003317

Razack, S. H. (2004). Imperilled Muslim women, dangerous Muslim men and civilized Europeans: Legal and social responses to forced marriages. Feminist Legal Studies, 12, 129 174. doi:10.1023/b:fest.0000043305.66172.92

Razack, S. H. (2007). The 'Shari'a law debate' in Ontario: The modernity/premodernity distinction in legal efforts to protect women from culture. Feminist Legal Studies, 15(1), 3 32. doi:10.1007/s10691-006-9050-x

Razack, S. H. (2008). Casting out: The eviction of Muslims from western law and politics. University of Toronto Press.

Rogan, M. (2008, December). Girl interrupted: The brief life of Aqsa Parvez. Toronto Life Magazine.

Spivak, G. C. (1996). Diasporas old and new: Women in the transnational world. Textual Practice, 10(2), 245-269. doi:10.1080/09502369608582246

Spivak, G. C. (2005). Use and abuse of human rights. Boundary 2, 32(1), 131-189. doi:10.1215/01903659-32-1-131

Tasker, J. P. (2016, February 16). Confusion reigns over number of missing murdered Indigenous women. CBC News. Retrieved from http://www.cbc.ca/news/politics/mmiw-4000hajdu-1.3450237

Thobani, S (2000). Closing the nation's doors to immigrant women: The restructuring of Canadian immigration policy. Atlantis, 24(2), 16-26.

Tuck, E., \& Yang, K. W. (2012). Decolonization is not a metaphor. Decolonization: Indigeneity, education \& society, 1(1), 1-40. https://jps.library.utoronto.ca/index.php/des/article/view/18630

Weldon, B. (2010). Restoring lost "honour": Retrieving face and identity, removing shame, and controlling the familial cultural environment through "honor" murder. Journal of Alternative Perspectives in the Social Sciences, 2(1), 380-398. 